\title{
Pass-through in dollarized countries: should Ecuador abandon the U.S. Dollar?
}

\author{
María Lorena Marí del Cristo*a and Marta Gómez-Puig ${ }^{\mathrm{b}}$
}

March 2013

\begin{abstract}
In this article we examine the convenience of dollarization for Ecuador today. As Ecuador is strongly integrated financially and commercially with the United States, the exchange rate pass-through should be zero. However, we sustain that rising rates of imports from trade partners other than the United States and subsequent real effective exchange rate depreciations are causing the pass-through to move away from zero. Here, in the framework of the Vector Error Correction Model, we analyse the impulse response function and variance decomposition of the inflation variable. We show that the developing economy of Ecuador is importing inflation from its main trading partners, most of them emerging countries with appreciated currencies. We argue that if Ecuador recovered both its monetary and exchange rate instruments it would be able to fight against inflation. We believe such an analysis could be extended to other countries with pegged exchange rate regimes.
\end{abstract}

JEL Classification: E31; F31; F41.

Keywords: Pass-through, shocks, dollarized countries, structural VECM.

The authors would like to express their gratitude to Andrea Cipollini, Barbara Pistoresi and Antonio Ribba for helpful comments. ${ }^{a}$ Department of Economics. University of Barcelona, Av.Diagonal 690. Barcelona 08034. Email: Imari@ub.edu. ${ }^{b}$ Department of Economics. University of Barcelona and RiskCenter-IREA, Av. Diagonal 690. Barcelona 08034. Email: marta.gomezpuig@ub.edu. This article is based upon work supported by the Government of Spain and FEDER under grant number ECO2010-21787-C03-01. *Corresponding author: Lorena Marí. E-mail: lmari@ub.edu 


\section{Introduction}

Selecting the optimal exchange rate regime for developing and emerging countries is the subject of ongoing debate in international economic forums, especially in light of the current global economic crisis that has called into question most exchange rate regimes ${ }^{1}$. Given the variety of such regimes ${ }^{2}$, the exchange rate pass-through (ERPT) literature, which examines the inflationary pressure attributable to the transmission mechanism of the exchange rates, is presented as a useful framework for exploring the economic implications of these regimes and identifying the most convenient exchange rate mechanism for a given country. Here, we focus our study on the pegged exchange rate regime adopted in Ecuador, a dollarized country which is currently undergoing major political and economic changes that might result in changing its exchange rate regime in the near future ${ }^{3}$.

In theory, dollarized countries should have a very low pass-through as their currencies are anchored to that of their principal trade partner. In Ecuador, the appearance of inflationary pressure due to pass-through might reflect the fact it has begun to substitute its traditional trade partners. China, for example, was the leading merchandise exporter in 2010 ( $\$ 1.58$ trillion, or $10 \%$ of world exports) and accounted for $7.8 \%$ of Ecuador's total imports ${ }^{4}$. Fig. 1 in Appendix B shows the appreciation of the Chinese yuan (CNY) against the US dollar (USD). When China reformed its fixed exchange rate regime to a

\footnotetext{
${ }^{1}$ Even the European Monetary Union, the benchmark for economies undertaking similar projects, has been questioned in terms of a deficient political and fiscal union (Issing, 2011).

${ }^{2}$ Reinhart \& Rogoff (2004) used market-determined exchange rates (from dual/parallel markets) and found fourteen categories of exchange rate regimes, ranging from no separate legal tender or a strict peg to a dysfunctional "freely falling" or "hyperfloat".

${ }^{3}$ Ecuador is a member of major Latin American economic organizations including UNASUR (www.uniondenacionessuramericanas.com), CAN (www.comunidadandina.org), ALBA (www.alianzabolivariana.org), which in 2007 created the Bank of the South - a credit institution similar to the World Bank, and it is soon to join MERCOSUR(MERCOSUR/CMC/DEC. N $\mathrm{N}^{\mathrm{o}} 38 / 11$ ). The aim of these organizations is to create a South American Free Trade Area, using a new currency (the sucre), which was first used in 2010 as a virtual currency in at least two transactions between Ecuador and Venezuela. Ecuador is also diversifying its trade partners, with Asian countries being its leading exporters in 2010 (www.icex.es).

${ }^{4}$ Reported by the World Trade Organization in 2011 Press Releases (PRESS/628).
} 
managed floating exchange rate system in July $2005^{5}$, one USD was valued at 8.2700 CNY. In January 2012 one USD was worth 6.3548 CNY, an appreciation of $23.15 \%$. Likewise, the rates of appreciation experienced by two currencies belonging to two of Ecuador's main trade partners, Colombia and Japan, are shown in Fig. 2 (Appendix B).

In times of crisis, the ERPT plays a crucial role in achieving an internal and external balance. When the ERPT is high, variations in the exchange rate result in changes in the relative prices of tradable and non-tradable commodities generating a rapid adjustment in the trade balance. At the same time, high ERPT also encourages domestic production to substitute imported products.

In general, developing countries are heavily dependent on imports. These imported products become more expensive following episodes of depreciation, thereby affecting the economic growth of these countries in terms of levels of investment and consumption. As developing countries are unlikely to renounce imported products, as the pass-through rises, the rate of inflation with which they have to contend also grows. In a currency crisis, therefore, developing countries find themselves most severely affected owing to the deterioration in the balance sheet of financial institutions as they borrow in foreign currencies from foreign institutions, but lend in the domestic currency to domestic firms. If the national currency is depreciated these liabilities are magnified, and the banks are unable to lend and investors send their profits abroad (capital flights), resulting in contractionary effects in the economy ${ }^{6}$.

When a country is dollarized it can overcome a high ERPT coefficient and its balancesheet problems as long as the United States continues to be its principal lender and commercial partner. Yet, what happens if this situation should change? Fig. 3 in

${ }^{5}$ This new system replaced the USD, which had served as the sole anchor currency for approximately ten years, with a basket of currencies that was weighted to account for bilateral trade volume and bilateral investment.

${ }^{6}$ Frankel (2005) in his article "Contractionary currency crashes in developing countries" describes how depreciations of the national currency cause contractionary effects rather than an expansion in economies highly indebted in dollars. 
Appendix B shows the evolution in Ecuador's main suppliers over the period 1998 to 2010. Although United States remains the main trading country, Latin America is the leader among the regions, comprising the Latin American Integration Association (Argentina, Brazil, Chile, and Mexico) and the Andean Community (Bolivia, Colombia, Peru and Venezuela). The figure also highlights the growth recorded by Asia (comprising Japan, Taiwan, China and South Korea), which since 2004 has replaced Europe as the third largest source of imports. Thus, as the trade relations between the two "monetary linked" countries weaken, the benefits to the dollarized country of operating a pegged exchange rate regime are reduced. Bastourre et al. (2003) found that if the financial channel (FC) becomes a more important transmission mechanism than the trade channel (TC), the FC will increase the gross domestic product (GDP) volatility of the dollarized country $^{7}$.

In conducting our research here, we selected a Latin American country, namely Ecuador, which was dollarized in 2000 principally to avoid escalating inflationary pressures. The study, undertaken in the framework of a Vector Error Correction Model (VECM), examines a period that extends from January 2000 to July 2011 (i.e., covering ten years of dollarization and part of the current global economic crisis).

The article is organized as follows. In the section that follows we provide a brief economic history of Ecuador. In section three, we present an overview of the passthrough literature, emphasizing the paucity of studies conducted for developing countries. In sections four and five, we describe the theoretical framework and the data and methodology adopted, respectively. Our empirical results are reported in section six and we draw our conclusions in section seven

\footnotetext{
${ }^{7}$ With business cycles negatively correlated, the FC increases real volatility and the TC reduces it. If the anchor country is hit by a positive shock, two simultaneous processes will take place: a) the anchor country will increase imports from the pegged country, positively affecting the GDP of this country through the TC, but b) since the anchor country could issue a restrictive monetary policy in order to avoid over-heating, the increase in the interest rate will negatively affect the pegged country through the FC.
} 


\section{Ecuador - a history of dollarization}

The relative advantages and drawbacks of official dollarization to a country are well documented $^{8}$. Thus, this exchange rate regime facilitates the control of inflation and interest rates, aids the stabilization of the exchange rate and ensures lower transaction costs; however, the process also entails high transition costs, while a country loses control over its monetary policy, its central bank no longer serves as a lender of last resort and, ultimately, a national symbol is lost.

There are three different degrees of dollarization: unofficial and semi-official - both of which are referred to as partial dollarization - and official or full dollarization. In Latin America and the Caribbean region alone all three regimes can be found ${ }^{9}$. This study is concerned with full dollarization in which the national currency is substituted by the US dollar as legal tender. Below, we briefly outline the monetary history of Ecuador, the country under analysis here.

Ecuador's national currency, the sucre, first launched in 1884 by the government of Jose Maria Placido Caamaño, was replaced as legal tender by the US dollar in 2000, at a rate of 25000 sucres per dollar. In the early 1990s, Ecuador introduced various structural reforms that provided a certain degree of macroeconomic stability at least until the middle of that decade. However, a number of endogenous shocks - including, an inefficient fiscal policy and increasing financial dollarization - and exogenous shocks - including the impact of the climate oscillation, el Niño, and international oil prices - immersed the country in a period of economic stagnation that saw macroeconomic imbalances increase (Jacome, 2004).

\footnotetext{
${ }^{8}$ See Alesina and Barro (2001), De Nicoló, Honohan and Ize, (2005), and Berg and Borensztein, E. (2000). ${ }^{9}$ Peru, Uruguay and Bolivia operate a high degree of financial dollarization (a variety of partial dollarization) in which foreign assets exceed domestic assets but where each country maintains its own currency. Haiti operates a system of semiofficial dollarization in which the foreign currency is legal tender, but where it plays a secondary role to the domestic currency for paying taxes and wages. Finally, only three countries are fully dollarized, namely, Ecuador, El Salvador and Panama.
} 
At the end of the twentieth century, Ecuador experienced one of the most serious crises in the history of the Republic with inflation rates being recorded at 30 percent per month. The government intervened in the banks and many public deposits were frozen. Internationally, Ecuador's standing was not good; it was in arrears with its private creditors and bondholders, while the International Monetary Fund, the World Bank and the Inter-American Development Bank withheld important loans that might have supported the Ecuadorian balance of payments.

The country was in urgent need of radical measures that would stabilize expectations, avoid acute currency depreciation and hyperinflation, and restore economic and financial activity. At the same time, the government was in urgent need of radical measures that would allow it to escape being overthrown. At its head, President Mahuad faced the challenges of severe social and economic crisis - real GDP fell 7.3 percent, unemployment rose from 11 to 15 percent and an active indigenous movement called for political and economic reform. In an attempt to switch the focus from political issues to economic matters, he concluded that the radical solution was dollarization.

Following dollarization, GDP rose by 2.3 percent in 2000, and climbed 5.4 percentage points in 2001. Inflation had been stabilized, but at the same time international oil prices recovered so the immediate effects of dollarization on Ecuador's economy were somewhat ambiguous. Today, Ecuador is a member of the Andean Community of Nations (CAN), a free trade area, and most of the members have a floating exchange rate regime. As such, Ecuador is at risk of experiencing what Argentina underwent when Brazil devalued the real in 1999. Argentina, operating a currency board system, was unable to adjust its exchange rate parity in order to recover competitiveness (Beckerman and Solimano, 2002). 


\section{A brief overview of the pass-through literature}

The study of exchange rate pass-through began with the "law of one price" and the Purchasing Power Parity (PPP) literature. Dornbusch (1985), drawing on evidence prepared for the New Palgrave dictionary of economics, presents an excellent definition and review of this literature. Today, pass-through - the degree to which exchange rate changes are passed through to price levels - has been identified as the main mechanism providing theoretical support for deviations from PPP. Since the 1980s, various empirical studies have examined ERPT to domestic prices (including import, producer and consumer prices), yet most of the literature has focused its attention on industrialized countries.

At the micro level, Dornbusch (1987) applied industrial organization models to explain the relationship between exchange rate fluctuations and domestic price changes, in terms of market structure - import share and concentration - and the substitutability of imports for domestic products. The lower the level of product substitutability in an industry, and the greater the share of foreign exporters relative to domestic producers, the greater is the ability to maintain markups and, hence, the higher the pass-through rates rise. Campa and Goldberg (2002) analyzed twenty-five OECD countries estimating industry-specific rates of pass-through across and within countries and found a strong relationship between passthrough and the industry composition of trade. They conclude that the shift away from energy and raw materials as a high proportion of import bundles to a higher share of manufactured imports has contributed significantly to a reduction in pass-through. A number of other studies, including Obstfeld (2000), Goldberg and Knetter (1997), and Bacchetta and van Wincoop (2005), adopting Obstfeld and Rogoff's new open economy models, examine determinants such as the invoicing decisions of producers, import 
competition, oligopolistic pricing dynamics (or the pricing behaviour of firms) to explain the degree and speed of pass-through.

At the macro level, Froot and Kempleter (1988) associated a low pass-through rate with a higher nominal exchange rate variability, as importers became more wary of changing prices and more willing to adjust profits margins so as to maintain their local market share. However, if the exchange rate shock was expected to be persistent, then they were more likely to change prices than to adjust their profit margins ${ }^{10}$. An (2006) provides evidence to show that the size of a country's economy is inversely related to the passthrough coefficient while a country's trade openness (i.e. a higher share of imports) is directly related.

An additional macroeconomic factor, aggregate demand uncertainty, was introduced by Mann (1986): exporters will alter profit margins when aggregate demand shifts in tandem to exchange rate fluctuations in an imperfectly competitive environment, so countries with more volatile aggregate demand will have less pass-through ${ }^{11}$. A further determinant of pass-through, the inflation environment, is examined by Taylor (2000). He hypothesizes that declining rates of inflation lead to lower import price pass-through because firms in low inflation countries appear to have less pricing power than their counterparts in high inflation economies. A factor that is closely related to the inflation environment is the relative stability of monetary policy. Devereux et al. (2004) construct a model of endogenous exchange rate pass-through within an open economy macroeconomic framework. They report that when countries have differences in the volatility of money growth, firms in both countries will tend to fix their prices in the currency of the country that has more stable money growth, thereby reducing the impact of exchange rate changes on the country's domestic prices.

\footnotetext{
${ }^{10}$ A conclusion corroborated by Mann (1986) and Taylor (2000)

${ }^{11}$ McCarthy (2000) provides empirical evidence in confirmation of these hypotheses associating both exchange rate and GDP volatility with a lower exchange rate pass-through to domestic inflation, although these relationships were only strong at short horizons.
} 
Table 2 in Appendix A summarizes a number of recent articles that analyse pass-through in the dollarized economies of developing countries. Reinhart et al. (2003) and Carranza et al. (2009), among others, found pass-through to be higher in dollarized countries than it was in their non-dollarized counterparts; however, Gonzalez Anaya (2000) and AkofioSowah (2008) reported just the opposite. This can be accounted for by the fact that the former analysed countries in which dollarization was unofficial, while the latter studies looked at countries with official dollarization. While dollarization remains unofficial, a developing country retains its own local currency and so when this suffers depreciation there is a surge in "original $\sin ^{\text {"12, }}$, which explains why the balance-sheet is negatively affected by the currency mismatch with liabilities denominated in foreign currency.

\section{The Model}

The IS/LM framework, derived from Obstfeld et al. (1985), has been used by Shambaugh (2008) and Barhoumi (2007) so as to generate long-run restrictions. The model is based on a number of equations: simple aggregate demand, money demand, interest rate parity, price power parity (PPP) and import price setting:

$$
\begin{aligned}
& y_{t}^{d}=\alpha\left(s_{t}-p_{t}+p_{t}^{*}\right)-\beta\left(i_{t}-\mathbf{E}\left(p_{t+1}\right)-p_{t}\right)+r d_{t} \\
& m_{t}-p_{t}=y_{t}-\lambda i_{t} \\
& i_{t}=i_{t}^{*}+\mathbf{E}\left(\mathrm{s}_{\mathrm{t}+1}-\mathrm{s}_{\mathrm{t}}\right) \\
& q_{t}=s_{t}-p_{t}+p_{t}^{*} \\
& p m_{t}=\left(s_{t}+c x_{t}^{*}\right) N_{t}
\end{aligned}
$$

\footnotetext{
${ }^{12}$ See Eichengreen and Hausmann, 1999.
} 
where $y_{t}^{d}$ is the demand-determined output, $s_{t}$ is the nominal exchange rate, $p_{t}$ is the domestic price level, $p_{t}^{*}$ is the foreign price level, $r d_{t}$ is the relative world demand for home and foreign goods, $m_{t}$ is the money supply, $i_{t}$ and $i_{t}^{*}$ are the nominal interest rates of domestic and foreign countries respectively, and $q_{t}$ is the real exchange rate. Equation 5 relates the import price index, $p m_{t}$, with the cost of foreign exports, $c x_{t}^{*}$, and the markup on imports, $N_{t}$. All variables (except interest rates) are in natural logs.

The stochastic processes determining these variables are:

$$
\begin{aligned}
& y_{t}^{s}=y_{t-1}^{s}+a_{t} \\
& r d_{t}=r d_{t-1}+b_{t} \\
& m_{t}=m_{t-1}+c_{t} \\
& p_{t}^{*}=p_{t-1}^{*}+d_{t}
\end{aligned}
$$

In the long run, output is supply determined and prices make all necessary adjustments to achieve equilibrium. Therefore, on the assumption that prices are flexible in the long run, $\mathbf{E}\left(p_{t+1}-p_{t}\right)$ is equal to zero. Additionally, we assume that the real interest rate is constant and normalize it to zero. This means the long-run interest rate is zero, and so the interest rate drops out of the output and price equations. Based on these assumptions, the following equilibrium equations can be generated for our variables:

$y^{d}=y_{t}^{s}=y_{t-1}^{s}+a_{t}$

where $y^{s}$ is the supply-determined output.

$$
\begin{aligned}
& q_{t}=\left(y_{t-1}^{s}+a_{t}-r d_{t-1}-b_{t}\right) / \alpha \\
& p_{t}=m_{t-1}+c_{t}-y_{t-1}^{s}-a_{t} \\
& s_{t}=\left[\frac{y_{t-1}^{s}+a_{t}-r d_{t-1}-b_{t}}{\alpha}\right]+\left[m_{t-1}+c_{t}-y_{t-1}^{s}-a_{t}\right]-\left[p_{t-1}^{*}+d_{t}\right]
\end{aligned}
$$


If we assume that $c x_{t}^{*}$ is affected by the same shock affecting the foreign price level $\left(p_{t}^{*}\right)$, the import prices can be explained by the following expression:

$$
\begin{aligned}
& p_{m t}=\left[\frac{y_{t-1}^{s}+a_{t}-r d_{t-1}-b_{t}}{\alpha}\right] N_{t}+\left[m_{t-1}+c_{t}-y_{t-1}^{s}-a_{t}\right] N_{t} \\
& -\left[p_{t-1}^{*}+d_{t}\right] N_{t}+\left[c x_{t-1}^{*}+d_{t}\right] N_{t}
\end{aligned}
$$

According to these equations, $y_{t}^{s}$ is only affected by $a_{t}$ in the long run and the variable $q_{t}$ is only affected by $a_{t}$ and $b_{t}$ in the long run. Prices $\left(p_{t}\right)$ are only affected by both $c_{t}$ and $a_{t}$ and all these shocks, jointly with $d_{t}$, affect the nominal exchange rate. Import prices are likewise affected by all these shocks since they depend on the exchange rate and foreign exporter costs.

\section{Data and empirical methodology}

\section{Data}

In line with most of the studies summarised in Table 2 of Appendix A, we specify a Vector Error Correction Model (VECM) in order to detect all shocks involving the variables included in the theoretical model and so as to avoid missing any information for the variables in levels. The model includes four endogenous variables: $\mathrm{x}_{\mathrm{t}}=\left[d 1_{-}\right.$cpi, reer, $R I D L, o i l]^{13}$. The first variable, inflation $\left(d l_{-} c p i\right)$, or first difference of the consumer price index of Ecuador, detects the inflationary pressures generated by the rest of the variables.

The real effective exchange rate (reer) captures both demand and foreign costs. It measures the transmission of the real exchange rate of the domestic currency (US dollar) and the currencies of Ecuador's main trading partners. It is trade weighted and based on

\footnotetext{
${ }^{13}$ See Table 1 in Appendix A for details of data sources.
} 
the relative $\mathrm{CPI}^{14}$. This variable indicates if the pass-through is rising because of the differential between Ecuadorian inflation and that of its principal trade partners. This variable can also be used as a proxy of the cost of foreign exports, considering that inflation has a negative and persistent effect on real GDP growth ${ }^{15}$ and hence on the foreign export sector. The real exchange rates are set so that a rise in the index is equivalent to depreciation. Thus, a real depreciation is considered as lower foreign costs. Indeed, other studies, including Shambaugh (2008) and Campa and Goldberg (2005), consider the nominal exchange rate as foreign prices ${ }^{16}$. As the real effective exchange rate includes nominal exchange rates in its formula, the former also generate foreign price shocks.

The freely available international reserves of the Central Bank of Ecuador (RIDL in its ) serve as the proxy for the money supply variable. This variable includes the principal taxes and oil export revenues used in financing government spending, imports and external debt, among other concepts.

The oil prices variable (oil) is set to capture supply shocks taking into consideration that this variable has been used historically to detect just such shocks and, given that Ecuador is an oil producer and exporter, these prices are liable to generate inflationary pressures through a real exchange rate appreciation (Dutch diseases) ${ }^{17}$. As a proxy for this variable, we chose the Europe Brent Spot Price FOB as opposed to the West Texas Intermediate (WTI) price, the traditional benchmark in oil pricing in Ecuador, because according to the

\footnotetext{
${ }^{14}$ The methodology for calculating the real effective exchange rate is outlined in Rodriguez (1999). The countries included are the US, Japan, Colombia, Germany, Italy, Spain, Brazil, Chile, Mexico, Venezuela, France, the UK, Peru, Belgium, Argentina, Netherlands, Panama and South Korea, which account for about $89 \%$ of Ecuador's total trade.

${ }^{15}$ See Hwang and Wu (2009) for China, Wilson (2006) for Japan, and Ma (1998) for Colombia, three of Ecuador's leading trade partners, and included in the calculation of Ecuador's real effective exchange rate.

${ }^{16}$ They assume foreign price shocks to be equivalent to nominal exchange rate shocks because when the latter changes persistently without changes to either the real exchange rate or domestic prices, the change is only recorded in foreign prices and the nominal exchange rate.

${ }^{17}$ The higher real income resulting from a boom leads to extra spending on services, which in turn raises their price (i.e. causes a real exchange rate appreciation, defined as the relative price of non-traded to traded goods), where the boom is experienced in the extractive sector, and it is the traditional manufacturing sector that is placed under pressure (Corden and Neary, 1982).
} 
Ecuadorian Minister of Petroleum and Mines, Wilson Pastor, the country's crude oil price is determined by Brent rather than by WTI. ${ }^{18}$

The Central Bank of Ecuador was the principal source used to collect these data but we have also drawn on the International Energy Agency to obtain oil prices. Monthly data spanning the period 2000:01-2011:07 are transformed to logarithms but not seasonally adjusted, since such an adjustment could modify the relations between the variables ${ }^{19}$.

\section{Empirical methodology}

We initially tested for stationarity. We used the unit root test with level shifts LLS proposed by Saikkonen and Lütkepohl (2002) and Lanne et al. (2002) to take into account any possible structural breaks in the data ${ }^{20}$. Both studies propose a unit root test based on estimating the deterministic term first using a generalized least squares (GLS) procedure under the unit root null hypothesis and then subtracting this from the original series. An Augmented Dickey-Fuller (ADF) type test is then performed on the adjusted series. If the break date is unknown, Lanne et al. (2003) recommend choosing a reasonably large autoregressive (AR) order in a first step and then selecting the break date which minimizes the GLS objective function used to estimate the parameters of the deterministic part. Critical values are tabulated in Lanne et al. (2002). The ADF test was also used for the data without structural breaks.

Next we test for cointegration by using the Saikkonen and Lütkepohl (2000a,b,c) test, which involves estimating the deterministic term in a first step, subtracting it from the observations and applying a Johansen type test to the adjusted series. The parameters of

\footnotetext{
${ }^{18}$ See the interview in http://internacional.elpais.com/internacional/2011/02/24/actualidad/1298502020_850215.html ${ }^{19}$ See Lütkepohl (2004).

${ }^{20}$ In a Monte Carlo simulation study, Lanne and Lütkepohl (2002) show that LLS tests, which estimate the deterministic term by a GLS procedure under the unit root null hypothesis, enable remarkable gains in size and power properties and perform best in comparison to those tests which accommodate a deterministic level shift by estimating the deterministic term by OLS procedures.
} 
the deterministic term are estimated by the GLS procedure. The critical values depend on the kind of deterministic term included. Possible options are a constant, a linear trend term, a linear trend orthogonal to the cointegration relations and seasonal dummy variables. In other words, all the options available for the Johansen trace tests are also available in this test. In addition, the critical values remain valid if a shift dummy variable is included. Critical values and p-values were generated according to Trenkler (2004).

The Johansen (1995) reduced rank regression procedure was applied to estimate the VECM, which we ran with different lags until we ensured the nonautocorrelation, homoscedasticity and the no presence of ARCH effects.

Restrictions on the long-run effects of some shocks were used to identify these models (see Blanchard and Quah, 1989; Gali, 1999; and King et al., 1991).

Having estimated the reduced form of VECM:

$\Delta y_{t}=\Pi y_{t-1}+\Gamma_{1} \Delta y_{t-1}+\cdots+\Gamma_{p-1} \Delta y_{t-1}+C D_{t}+u_{t}$

Derived from the structural form:

$A \Delta y_{t}=\Pi^{*} y_{t-1}+\Gamma_{1}^{*} \Delta y_{t-1}+\cdots+\Gamma_{p-1}^{*} \Delta y_{t-1}+C^{*} D_{t}+B_{t} v_{t}$

where $y_{t}$ contains all the variables included in the model, as justified above. $D_{t}$ contains all regressors associated with determinist terms; $\Pi^{*}, \Gamma_{j}^{*}(j=1 \ldots, p-1), C^{*}$ and $B_{t}$ are structural form parameters. Matrix $A$ contains all the instantaneous relations between the variables, and $v_{t}$ is a $(\mathrm{Kx} 1)$ structural form error term that is typically a zero mean white noise process with time- invariant covariance matrix $\sum_{v}$.

The reduced form is given in Equation (17)

With $\Gamma_{1}=A^{-1} \Gamma_{1_{J}^{*}}^{*}(j=1 \ldots, p-1), C=A^{-1} C^{*}, \Pi=A^{-1} \Pi^{*}, u_{t}=A^{-1} B v_{t}$. 
It has the following moving-average (MA) representation:

$y_{t}=\Xi \sum_{\mathrm{i}=1}^{\mathrm{t}} \mathrm{u}_{\mathrm{i}}-\Xi^{*}(\mathrm{~L}) \mathrm{u}_{\mathrm{i}}+\mathrm{y}_{0}^{*}$

Where $\Xi=\beta_{\perp}\left(\alpha_{\perp}^{\prime}\left(I_{\mathrm{k}}-\sum_{\mathrm{i}=1}^{\mathrm{p}-1} \Gamma_{i}\right) \beta_{\perp}\right)^{-1} \quad \alpha_{\perp}^{\prime}, \quad \Xi^{*}(\mathrm{~L})=\sum_{\mathrm{j}=0}^{\infty} \Xi_{\mathrm{j}}^{*} \mathrm{~L}^{\mathrm{j}}$

is an infinite order polynomial in the lag operator with a coefficient matrix $\Xi_{\mathrm{j}}^{*}$ that goes to zero as $\mathrm{j}$ goes to infinity. The matrix $\Xi$ has rank $\mathrm{K}-\mathrm{r}$ if the cointegrating rank of the system is $\mathrm{r}$ and it represents the long-run effects of forecast error impulse responses, while $\Xi_{\mathrm{j}}^{*}$ represents transitory effects. The term $y_{0}^{*}$ contains all initial values. As the forecast error impulse responses based on $\Xi$ and $\Xi_{\mathrm{j}}^{*}$ are subject to the same criticism as those for stable VAR processes, appropriate shocks have to be identified for a meaningful impulse response analysis. If $u_{t}$ is replaced by $A^{-1} B v_{t}$, the orthogonalized short-run impulse responses may be obtained as $\Xi_{\mathrm{j}}^{*} A^{-1} B$ in a way that is analogous to the stationary vector autoregressive (VAR) case. Moreover, the long-run effects of $u_{t}$ shocks are given by $\Xi A^{-1} B(18)$.

This matrix has rank $\mathrm{K}-\mathrm{r}$ because $\operatorname{rk}(\Xi)=\mathrm{K}-\mathrm{r}$ and $A$ and $\mathrm{B}$ are non singular. Thus, the matrix (18) can have at most $r$ columns of zeros. Hence, there can be at most $r$ shocks with transitory effects (zero long-run impact), and at least $\mathrm{k}^{*}=\mathrm{K}-\mathrm{r}$ shocks have permanent effects. Given the reduced rank of the matrix, each column of zeros stands for only $\mathrm{k} *$ independent restrictions. Thus, if there are $\mathrm{r}$ transitory shocks, the corresponding zeros represent $\mathrm{k}^{*} \mathrm{r}$ independent restrictions only. To identify the permanent shocks exactly we need $\mathrm{k}^{*}\left(\mathrm{k}^{*}-1\right) / 2$ additional restrictions. Similarly, $\mathrm{r}(\mathrm{r}-1) / 2$ additional contemporaneous restrictions identify the transitory shocks. Together these constitute a 
total of $\mathrm{k}^{*} \mathrm{r}+\mathrm{k}^{*}\left(\mathrm{k}^{*}-1\right) / 2+\mathrm{r}(\mathrm{r}-1) / 2=\mathrm{K}(\mathrm{K}-1) / 2$ restrictions ${ }^{21}$. If we assume that $A=\mathrm{I}_{\mathrm{k}}$,

the matrix (18) become $\Xi \mathrm{B}$, and we have enough restrictions to identify $\mathrm{B}$ with the longrun restrictions explained above.

\section{Empirical results and discussion.}

The results of the standard ADF test and the unit root test with a level shift proposed by Saikkonen and Lütkepohl (2002) and Lanne et al. (2002) for those variables with structural breaks (presented in Tables 1 and 2 in Appendix C) indicate that the series in level terms display a unit root and in difference terms (denoted by d1) are stationary ${ }^{22}$.

The graphics show the presence of structural breaks in the following variables: inflation (d1_cpi), real effective exchange rate (reer) and oil prices (oil). Since inflation and the real effective exchange rate variables are highly correlated, both present the same break date: 2001:M2, while for oil prices the break date is 2009:M1.

The results of the Saikkonen and Lütkepohl cointegration test $(2000 \mathrm{a})^{23}$, presented in Table 3 in Appendix C, suggest that all variables cointegrate through one cointegration relation ${ }^{24}$.

The Johansen (1995) reduced rank estimation procedure was applied in estimating the VEC model, which has five lags for variables in difference and just one lag for the

\footnotetext{
${ }^{21}$ See Breitung, J., Brüggemann, R. and Lütkepohl, H. (2004).

${ }^{22}$ The econometric analysis was implemented using JmulTi 4 software (www.jmulti.de).

${ }^{23}$ If we had not obtained cointegration without the inclusion of dummies so as to take the structural breaks into account, then we would have included them, but it proved unnecessary because the structural breaks coincided in more than one variable. It is supposed that the cointegration relation absorbed these structural breaks. See Juselius, 2007.

${ }^{21}$ We reach the same conclusion with the Johansen Trace test (Johansen, Mosconi and Nielsen, 2000). In the test we specified $1 \mathrm{lag}$ for the variables in levels, two level shifts (2001:M2 and 2009:M1) unrestricted in the model, but seasonal dummies, intercept and trend restricted in the model. We estimate our VECM with the Johansen reduced rank, keeping this structure.
} 
cointegrated vector, ensuring the nonautocorrelation, homoscedasticity and the no presence of ARCH effects.

Even when structural breaks were absorbed in the cointegration space, two dummy variables had to be included in order to obtain the normality of residues. The first impulse dummy (dummy01) accounts for the new dollarization period that Ecuador entered in 2001, when its nominal variables seemed to be stable. This was 1 for 2001:M2 and -1 for 2001:M3, reflecting the differentiation of a permanent impulse detected in 2001:M2 by prior unit root tests. The second dummy (dummy09) takes into account the sudden decrease in oil prices, which in terms of Ecuadorian money supply took place in 2008:M12. This structural break was detected in prior unit root tests as a level shift in the oil variable. Following Juselius' (2007) technique when using dummies in VEC models, as mentioned above, a shift dummy becomes a permanent dummy when the former is differentiated, i.e. dummy09 will be -1 in 2009:M1.

By examining the significant loading coefficients $\left(\alpha_{i j}\right)$ resulting from the VEC estimation (see Table 4 in Appendix C) through their t-values (based on OLS standard errors), it can be seen that each significant $\alpha_{\mathrm{ij}}$ corresponds to a normalized eigenvector $\left(\beta_{\mathrm{ij}}\right)$ with the opposite sign. When this occurs, then the cointegration relation is equilibrium correcting in the equation $\Delta \mathrm{x}_{\mathrm{ij}}$. Here we can see that the oil variable is the only one not adjusted with the long-run inflation relation. This result was expected since this variable does not depend on domestic variables.

In order to obtain the impulse response function and the variance decomposition of inflation variable we have to estimate a structural VEC using the long-run restrictions explained above. Since we have just one cointegration vector, we have $r=1$. Hence, there can be at most one shock with transitory effects (zero long-run impact), and at least three $\left(k^{*}=4-1\right)$ shocks should have permanent effects. Given the reduced rank of the matrix, 
each column of zeros stands for only $\mathrm{k}^{*}$ independent restrictions. Thus, if there is one transitory shock, the corresponding zeros represent three $\left(k^{*} \mathrm{r}\right)$ independent restrictions. To identify the permanent shocks exactly we need three $\left(\mathrm{k}^{*}\left(\mathrm{k}^{*}-1\right) / 2\right)$ additional restrictions. Since $r(r-1) / 2$ is zero, we do not need additional contemporaneous restrictions to identify the transitory shocks. Together these constitute a total of six $(\mathrm{K}(\mathrm{K}-1) / 2)$ restrictions.

With the vector of structural shocks given by $u_{t}=\left(u_{t}^{\Delta c p i}, u_{t}^{\text {reer }}, u_{t}^{\text {RIDL }}, u_{t}^{\text {oil }}\right)^{\prime}$, the contemporaneous impact matrix $B$ and the identified long run impact matrix $\Xi B$, would have the following restrictions:

$$
\mathrm{B}=\left(\begin{array}{llll}
* & * & * & * \\
* & * & 0 & * \\
* & * & * & * \\
* & * & * & *
\end{array}\right)
$$

$$
\Xi B=\left(\begin{array}{llll}
0 & * & * & * \\
0 & * & * & * \\
0 & * & * & * \\
0 & 0 & 0 & *
\end{array}\right)
$$

The cointegration analysis suggested that inflation is stationary, accordingly inflation has no long-run impact on the rest of the variables included in the model, which corresponds to four zero restrictions in the first column of the identified long-run impact matrix. To derive the rest of the restrictions we employ the theoretical model described in Section 4. If in the long run the output is supply determined, this restriction is imposed by setting the elements $\Xi \mathrm{B}_{4 j}, j=1,2,3$ equal to zero. We are interested in the long-run relation between money supply and inflation, even in a country which has lost control over its monetary policy; consequently, as we need one more restriction to identify the parameters in $\mathrm{B}$, we decided to impose one contemporaneous restriction, that is, $\mathrm{B}_{23}=0$, assuming that money supply does not affect the real effective exchange rate in the short run. This is a coherent approach as we are analyzing a country with a fixed exchange rate regime in which the authorities cannot call on international reserves to control it. 
The bootstrapped t-values summarized in Table 5 in Appendix C, obtained using 2,000 bootstrap replications, suggest that only real effective exchange rate shocks significantly increase inflation in the long run in Ecuador. In the short run only oil price shocks significantly increase the real effective exchange rate. Both results are consistent with the assumption that the real effective exchange rate involves both demand and foreign price shocks. Money supply does not affect inflation significantly in Ecuador, which is to be expected in a country that cannot use its monetary policy to affect prices, even when this variable is adjusted to the same long-run relation as the rest of the domestic variables (d1_cpi, reer). The oil variable is only affected by its own shocks in the short run.

While a pegged exchange rate regime serves to lower inflation in Ecuador, the rest of the world is experiencing higher rates of inflation. Thus, international currencies are appreciating in the long run, and rising oil prices exacerbate the effect by pushing inflation up in oil importing countries (Ecuador's foreign exporters). The impulse response graphs (Figure 6 in Appendix C) and the variance decomposition table (Table 6 in Appendix C) illustrate these results: real effective exchange rate depreciations increased inflation for about twenty periods with a maximal response after two years. Indeed, the graphs of the variables in Appendix $\mathrm{C}$ forecast these conclusions: the real effective exchange rate follows oil price trends, after dollarization, the real effective exchange rate fell reaching a low in 2003:M5. After that date the trend reversed, increasing until the two downturns in oil prices in 2009:M1 and 2010:M7.

\section{Conclusions}

In this article we have examined the impact of Ecuador's real effective exchange rate depreciations on domestic inflation rates in the period from January 2000 (when Ecuador officially adopted the US dollar as its domestic currency) to July 2011 (latest available 
data). We have drawn on the exchange rate pass-through literature and a structural VECM with long-run restrictions in undertaking the theoretical and empirical analyses.

Although few ERPT studies have specifically examined dollarized countries, AkofioSowah (2008) reports that officially dollarized countries, such as Ecuador, experience a significantly lower ERPT coefficient. However, the findings reported herein contradict this. With the estimation of the structural VECM, we obtain the impulse responses of inflation to a real effective exchange rate shock - these impulse responses can be interpreted as the trend presented by the exchange rate pass-through. As we have shown, the real effective exchange rate presents an upward trend, following the trend in oil prices. As an oil exporter, the higher Ecuadorian oil prices rise, the higher is the inflation suffered by oil importing countries. These countries are at the same time Ecuador's trading partners and so Ecuador imports the inflation of its main trading partners through these currency appreciations.

Today, the United States remains Ecuador's principal trading partner, but as emerging countries such as South Korea and Brazil increase their participation in Ecuadorian trade, the currencies of such countries can be expected to acquire greater importance than the US dollar in the Ecuadorian balance sheet: the higher the real effective exchange rate rises, the greater the inflationary pressures attributable to the higher pass-through in Ecuador. We believe the inflationary effect reported here would have been even more marked if we had included China in our real effective exchange rate calculations, given that China is the emerging country par excellence. However, owing to its relatively new flexible exchange rate regime, we resolved to postpone its study to a later date.

In our opinion, Ecuador needs to face its short-term economic future with caution since both banking and currency crises are harmful to the country's real and nominal variables. In light of the results, we honestly think that Ecuador is currently missing the opportunities afforded by managing its own currency and, most significantly, the 
opportunity of implementing its own monetary policy to manage the shocks it is experiencing.

\section{References}

Akofio-Sowah, N. A. (2009) Is There a Link Between Exchange Rate Pass-Through and the Monetary Regime: Evidence from Sub-Saharan Africa and Latin America, International Advance Economic Research, 15, 296-309.

Alesina, A. and Robert, J. Barro (2001) Dollarization, The American Economic Review, 92, 381-385.

Alvarez, R., Jaramillo, P. and Selaive, J. (2008) Exchange rate pass-through into import prices: the case of Chile, Central Bank of Chile Working Papers No. 465.

Amisano, G. and Giannini, C. (1997) Topics in structural VAR econometrics, 2nd edn, Springer, Berlin and New York.

An, L. (2006) Exchange Rate Pass-Through: Evidence Based on Vector Autoregression with Sign Restrictions, Discussion Paper No. 527, MPRA.

Bacchetta, P. and Eric van Wincoop. (2005) A Theory of the Currency Denomination of International Trade, Journal of International Economics, 67, 295-319.

Barhoumi, K. (2005) Exchange rate pass-through into import prices in developing countries: an empirical investigation, Economics Bulletin, 3, 1-14.

Barhoumi, K. (2007) Exchange rate pass-through and structural macroeconomic shocks in developing countries: an empirical investigation, Discussion Paper No. 6573, MPRA.

Barhoumi, K, and Jouini, J. (2008) Revisiting the Decline in the Exchange Rate PassThrough: Further Evidence from Developing Countries, Economics Bulletin, 3, 1-10.

Bastourre, Carrera, Feliz and Panigo (2003) Dollarization and real volatility, CEPREMAP Working Papers in Economics No. 311. Available at http://www.cepremap.cnrs.fr.

Beckerman, P. and Solimano, A. (2002) Crisis and Dollarization in Ecuador. Stability, growth and social equity, Directions in Development Series, The World Bank, Washington, D.C.

Berg. A and Borensztein, E. (2000) The Pros and Cons of full dollarization, IMF Working Paper No. 00/50.

Bhundia, A. (2002) An empirical investigation of exchange rate pass-through in South Africa, IMF Working Paper No. 02/165.

Blanchard, O. and Quah, D. (1989) The Dynamic Effects of Aggregate Demand and Supply Disturbances, American Economic Review, 79, 665-673. 
Breitung, J., Brüggemann, R. and Lütkepohl, H. (2004) Structural vector autoregressive modelling and impulse responses, in Applied Time Series Econometrics, 1st edn (Eds) H. Lütkepohl and M. Krätzig, Cambridge University Press, Cambridge, pp. 159-196.

Campa, J. M. and Goldberg, L. S. (2002) Exchange Rate Pass-Through into Import Prices: A Macro or Micro Phenomenon?, Federal Reserve Bank of New York, Staff Report No. 149.

Campa, J. M., Goldberg, L., and González-Mínguez, J. (2005) Exchange Rate PassThrough to Import Prices in the Euro Area, NBER Working Paper No. 11632.

Carranza, L., Galdon Sanchez, E. and Gomez Biscarri, J. (2009) Exchange rate and inflation dynamics in dollarized economies, Journal of Development Economics. 89, 98108.

Corden W.M. and Neary J.P., (1982) Booming Sector and De-industrialisation in a Small Open Economy, The Economic Journal, 92, 829-831.

Coulibaly, D. and Kempf, H. (2010) Does inflation targeting decrease exchange rate passthrough in emerging countries?, Banque de France Working Papers No. 303.

De Nicoló, G., Honohan, P. and Ize, A. (2005) Dollarization of bank deposits: Causes and consequences, Journal of Banking \& Finance, 29, 1697-1727.

Devereux, M., Engel, C. and Storgaard, P. (2004) Endogenous Exchange Rate Passthrough when nominal prices are set in advance, Journal of International Economics, 63, 263-291.

Dickey, D. A. and Fuller, W. A. (1979) Estimators for autoregressive time series with a unit root, Journal of the American Statistical Association, 74, 427-431.

Dornbusch, R. (1987) Exchange Rates and Prices, American Economic Review, 77, 93106.

Dornbusch, R. (1985), Purchasing Power Parity, NBER Working Papers No. 1591.

Einchengreen, B. and Hausmann, R. (1999) Exchange rates and financial fragility, NBER Working Papers No. 7418.

Frankel, J. (2005) Contractionary Currency Crashes In Developing Countries, NBER Working Papers No. 11508.

Froot, K. A. and Klemperer, P. (1988) Exchange rate pass-through when market share matters, NBER Working Papers No. 2542.

Gali, J. (1999) Technology, employment, and the business cycle: Do technology shocks explain aggregate fluctuations?, American Economic Review, 89, 249-271.

Goldberg, P. and Knetter, M. (1997) Goods prices and exchange rates: what have we learned?, Journal of Economic Literature 35, 1243-1272.

Goldfajn, I. and Werlang, Sergio R.C. (2000) The Pass-through from Depreciation to Inflation: A Panel Study, Banco Central Do Brasil Working Papers No. 5. 
Gonzalez Anaya, J. A. (2000) Exchange Rate Pass-through and Partial Dollarization: Is there a Link?, Center for Research on Economic Development and Policy Reform Working Papers No. 81.

Hwang, Jen-Te; Wu, Ming-Jia (2011) Inflation and Economic Growth in China: An Empirical Analysis, China and World Economy, 19, 67-84.

Issing, O. (2011) The crisis of European Monetary Union - Lessons to be drawn, Journal of Policy Modeling, 33, 737 - 749.

Ito, T. and Sato, K. (2008) Exchange Rate Changes and Inflation in Post-Crisis Asian Economies: Vector Autoregression Analysis of the Exchange Rate Pass-Through, Journal of Money, Credit and Banking, 40, 1407-1438.

Jacome, L. (2004) The late 1990s financial crisis in Ecuador: institutional weaknesses, fiscal rigidities, and financial dollarization at work, IMF Working Papers No. 04/12.

Johansen, S., Mosconi, R. and Nielsen, B. (2000) Cointegration analysis in the presence of structural breaks in the deterministic trend, Econometrics Journal, 3, 216-249.

Johansen, S. (1995) Likelihood-based Inference in Cointegrated Vector Autoregressive Models, 1st edn, Oxford University Press, Oxford.

Juselius, K (2006) The Cointegrated VAR Model: Methodology and Applications, 1st edn, Oxford University Press, USA.

King, G, Plosser, I, Stock, H and Watson, W. (1991) Stochastic Trends and Economic Fluctuations, American Economic Review, 81, 819-840.

Lanne, M., Lütkepohl, H. (2002). Unit root tests for time series with level shifts: a comparison of different proposals. Economics Letters 75(1): 109-114.

Lanne, M., Lütkepohl, H. and Saikkonen, P. (2002) Comparison of unit root tests for time series with level shifts, Journal of Time Series Analysis, 23, 667-685.

Lanne, M., Lütkepohl, H. and Saikkonen, P. (2003) Test procedures for unit roots in time series with level shifts at unknown time, Oxford Bulletin of Economics and Statistics, 65 , $91-115$.

Lütkepohl, H. (2004) Univariate time series analysis in Applied Time Series Econometrics, 1st edn (Eds) H. Lütkepohl and M. Krätzig, Cambridge University Press, Cambridge, pp. 8-85.

Ma, H. (1998) Inflation, uncertainty and growth in Colombia, IMF Working Papers No. $98 / 161$

Mann, C.L. (1986) Prices, Profit Margins and Exchange Rates, Federal Reserve Bulletin, 72, 366-379.

McCarthy, J. (2000) Pass-through of exchange rates and import prices to domestic inflation in some industrialized economies, Federal Reserve Bank of New York Staff Report No. 111.

Obstfeld, M. (1985), Cooper, R. and Krugman, P. (1985) Floating Exchange Rates: Experience and Prospects, Brookings Papers on Economic Activity, 2, 369-464. 
Obstfeld, M. (2000) International Macroeconomics: Beyond the Mundell-Fleming Model, IMF Staff Papers, Vol. 47.

Reinhart, C., Rogoff, K. and Savastano, M. (2003) Addicted to dollars, NBER Working Papers No. 10015.

Reinhart, C and Rogoff, K. (2004) The Modern History of Exchange Rate Arrangements: A Reinterpretation, Quarterly Journal of Economics, 119, 1-48.

Rodriguez, F. (1999) Metodología de cálculo de los índices de tipo de cambio real del Ecuador, Cuaderno de Trabajo No. 119. Available at http://www.bce.fin.ec/frame.php?CNT=ARB0000006.

Rowland, P. (2004) Exchange Rate Pass-Through to Domestic Prices: the Case of Colombia, Revista ESPE, 47, 106-125.

Saikkonen, P. and Lütkepohl, H. (2000a) Testing for the cointegrating rank of a VAR process with an intercept, Econometric Theory, 16, 373-406.

Saikkonen, P. and Lütkepohl, H. (2000b) Testing for the cointegrating rank of a VAR process with structural shifts, Journal of Business \& Economic Statistics, 18, 451-464.

Saikkonen, P. and Lütkepohl, H. (2000c) Trend adjustment prior to testing for the cointegrating rank of a vector autoregressive process, Journal of Time Series Analysis, 21, 435-456.

Saikkonen, P. and Lütkepohl, H. ( 2002) Testing for a unit root in a time series with a level shift at unknown time, Econometric Theory, 18, 313-348.

Shambaugh, J. (2008) A New Look at Pass-through, Journal of International Money and Finance, 27, 560-591.

Taylor, J. B. (2000) Low Inflation, Pass-Through, and the Pricing Power of Firms, European Economic Review, 44, 1389-1408.

Trenkler, C. (2004) Determining p-values for systems cointegration tests with a prior adjustment for deterministic terms, Center for Applied Statistics and Economics (CASE) Working Papers No. 37, Humboldt-Universitätzu Berlin.

Wilson, Bradley Kemp (2006) The Links between Inflation, Inflation Uncertainty and Output Growth: New Time Series Evidence from Japan, Journal of Macroeconomics, 28, 609-620. 


\section{$\underline{\text { Appendix A. Data and literature review }}$}

\section{Table 1. Data Sources}

\begin{tabular}{|l|l|}
\hline Consumer price index & \multirow{2}{*}{ Central Bank of Ecuador. For rapid access: } \\
\cline { 1 - 1 } Real effective exchange rate & http://www.bce.fin.ec/docs.php?path=/home1/estadisticas/bolmensual/IEMensual.jsp \\
\cline { 1 - 2 } $\begin{array}{l}\text { Freely available } \\
\text { international reserves }\end{array}$ & \\
\hline $\begin{array}{l}\text { Europe Brent Spot Price } \\
\text { FOB (Dollars per Barrel) }\end{array}$ & \\
\hline
\end{tabular}

Table 2. Literature Review

\begin{tabular}{|c|c|c|c|}
\hline Article & Data/Objective & $\begin{array}{l}\text { Method/Variables } \\
\text { involved }\end{array}$ & Results \\
\hline $\begin{array}{l}\text { Coulibaly, } \\
\text { D \& } \\
\text { Kempf, H. } \\
(2010)\end{array}$ & $\begin{array}{l}\text { Quarterly. } 27 \\
\text { emerging } \\
\text { countries, } \\
\text { 1989:1 - 2009:1. } \\
\text { To examine the } \\
\text { effect of } \\
\text { inflation } \\
\text { targeting on the } \\
\text { ERPT to prices. }\end{array}$ & $\begin{array}{l}\text { Panel VAR. Seven } \\
\text { seasonally adjusted } \\
\text { variables: bilateral } \\
\text { exchange rate vis-à-vis } \\
\text { US dollar, output gap, } \\
\text { log of world oil prices, } \\
\text { log of money supply, } \\
\text { consumer, and import } \\
\text { and producer price } \\
\text { indexes. }\end{array}$ & $\begin{array}{l}\text { The adoption of inflation targeting helps to reduce the pass- } \\
\text { through (PT) to all three price indexes in targeting countries. } \\
\text { Variance decomposition shows that the contribution of } \\
\text { exchange rate shocks to price fluctuations is more important } \\
\text { in emerging targeters than it is in nontargeters, and the } \\
\text { contribution of exchange rate shocks to price fluctuations in } \\
\text { emerging targeters declines after adopting inflation targeting. }\end{array}$ \\
\hline $\begin{array}{l}\text { Akofio } \\
\text { Sowah, N. } \\
(2009)\end{array}$ & $\begin{array}{l}\text { Quarterly. } 15 \\
\text { Sub-Saharan } \\
\text { and } 12 \text { Latin } \\
\text { American } \\
\text { countries, 1980- } \\
\text { 2005. To } \\
\text { investigate the } \\
\text { relationship } \\
\text { between the } \\
\text { monetary } \\
\text { regime and the } \\
\text { ERPT. }\end{array}$ & $\begin{array}{l}\text { Panel Data. Consumer } \\
\text { price index, nominal } \\
\text { and real effective } \\
\text { exchange rates, export } \\
\text { partners' production } \\
\text { cost (CPI* } \\
\text { NEER/REER), lagged } \\
\text { difference in the log of } \\
\text { CPI as a measure of } \\
\text { inflation persistence, } \\
\text { real GDP, trade } \\
\text { openness (M+X/GDP), } \\
\text { and exchange rate } \\
\text { volatility (SD of the } \\
\text { NEER over four } \\
\text { quarters). }\end{array}$ & $\begin{array}{l}\text { ERPT is incomplete and countries that are officially } \\
\text { dollarized experience a significantly lower ERPT coefficient. } \\
\text { The effects of size and trade openness variables on ERPT are } \\
\text { not significant. The effect of exchange rate volatility on PT is } \\
\text { significantly negative in Latin American countries and } \\
\text { significantly positive in Sub-Saharan Africa, as in the latter } \\
\text { region ER movements are perceived as permanent while in } \\
\text { the former region they are seen as being transitory. Thus, } \\
\text { Latin American firms are more willing to adjust their } \\
\text { markups. }\end{array}$ \\
\hline $\begin{array}{l}\text { Carranza, } \\
\text { Galdon } \\
\text { Sanchez } \\
\text { and Gomez } \\
\text { Biscarri }\end{array}$ & $\begin{array}{l}\text { Quarterly. } 124 \\
\text { countries with } \\
\text { different levels } \\
\text { of dollarization, } \\
\text { 1996-2004. }\end{array}$ & $\begin{array}{l}\text { Panel data. A quarterly } \\
\text { 12-month CPI inflation } \\
\text { rate as a measure of } \\
\text { inflation. Exchange rate } \\
\text { depreciation rates are } \\
\text { calculated quarterly }\end{array}$ & $\begin{array}{l}\text { HDEs present higher pass-through coefficients but, when the } \\
\text { nominal depreciation is large, this relationship changes: large } \\
\text { depreciations tend to reduce the extent of the pass-through, } \\
\text { the effect becoming more intense the more dollarized the } \\
\text { economy is. The exchange rate regime matters: countries } \\
\text { with fixed exchange rates present a more marked balance- }\end{array}$ \\
\hline
\end{tabular}




\begin{tabular}{|c|c|c|c|}
\hline (2009) & $\begin{array}{l}\text { To provide an } \\
\text { in-depth } \\
\text { analysis of the } \\
\text { pass through } \\
\text { from exchange } \\
\text { rate changes } \\
\text { into inflation by } \\
\text { taking into } \\
\text { account the } \\
\text { likely balance- } \\
\text { sheet effect } \\
\text { present in } \\
\text { highly } \\
\text { dollarized } \\
\text { economies } \\
\text { (HDE) }\end{array}$ & $\begin{array}{l}\text { using the nominal } \\
\text { exchange rate expressed } \\
\text { in units of local } \\
\text { currency per dollar. The } \\
\text { ratio of exports plus } \\
\text { imports to GDP to } \\
\text { measure the openness of } \\
\text { a country. Real GDP } \\
\text { growth to control the } \\
\text { business cycle. Real } \\
\text { Gross Fixed Capital } \\
\text { Formation growth } \\
\text { (GFCF). Two dummies } \\
\text { that control for fixed } \\
\text { and intermediate } \\
\text { regimes. }\end{array}$ & $\begin{array}{l}\text { sheet effect, whereas the evidence for intermediate regimes is } \\
\text { weaker and countries with flexible regimes do not seem to } \\
\text { experience the balance-sheet effect at all. A contraction in } \\
\text { investment may indeed be the mechanism that generates the } \\
\text { reduction in inflation pass-through. Openness appears } \\
\text { positively related to the intensity of pass-through. The } \\
\text { inclusion of GDP growth has an interesting effect: fast } \\
\text { growing countries show smaller inflation pass-through. }\end{array}$ \\
\hline $\begin{array}{l}\text { Alvarez, } \\
\text { Jaramillo } \\
\text { and Selaive } \\
(2008)\end{array}$ & $\begin{array}{l}\text { Monthly 1996- } \\
2007 . \\
\text { To estimate a } \\
\text { pass-through } \\
\text { into } \\
\text { disaggregated } \\
\text { import data in } \\
\text { Chile. }\end{array}$ & $\begin{array}{l}\text { Single equation model. } \\
\text { Nominal effective } \\
\text { exchange rate, but with } \\
\text { the NEER expressed as } \\
\text { US dollar parity they } \\
\text { obtained similar results. } \\
\text { As a proxy for foreign } \\
\text { prices: external price } \\
\text { index. Commodities } \\
\text { price index (minus fuel) } \\
\text { to control for changes in } \\
\text { import prices. Monthly } \\
\text { index of economic } \\
\text { activity. Seasonally } \\
\text { adjusted. Dummy } \\
\text { variables to test if PT is } \\
\text { asymmetric }\end{array}$ & $\begin{array}{l}\text { In Chile the PT is high. The evidence of asymmetric PT for } \\
\text { the aggregate import indexes is weak and none is found to } \\
\text { indicate that the high PT is attributable to the concentration } \\
\text { of Chilean imports in products with high ERPT. Yet } \\
\text { regressions suggest heterogeneity in ERPT for individual } \\
\text { products. }\end{array}$ \\
\hline $\begin{array}{l}\text { Ito, T. and } \\
\text { Sato, K. } \\
(2008)\end{array}$ & $\begin{array}{l}\text { Monthly from } \\
\text { 1994-2006. To } \\
\text { examine pass- } \\
\text { through effects } \\
\text { of exchange rate } \\
\text { changes on } \\
\text { domestic prices } \\
\text { in East Asian } \\
\text { countries. }\end{array}$ & $\begin{array}{l}\text { VAR. Five variables: } \\
\text { CPI, producer (PPI) and } \\
\text { import price index (IPI), } \\
\text { log of oil prices, output } \\
\text { gap, log of money } \\
\text { supply, nominal } \\
\text { effective exchange rate. } \\
\text { All prices and industrial } \\
\text { production index are } \\
\text { adjusted seasonally. } \\
\text { Another VAR including } \\
\text { interest rates. }\end{array}$ & $\begin{array}{l}\text { The pass-through effect is greatest on IPI, followed by that } \\
\text { on PPI, and is smallest on CPI. The degree of price response } \\
\text { to the exchange rate shock is greatest in Indonesia being } \\
\text { most pronounced in its CPI. Only Indonesia presents } \\
\text { positive, large and statistically significant impulse responses } \\
\text { of its monetary base to the NEER shock and of its CPI to the } \\
\text { monetary shock. Indonesia's disappointing recovery after the } \\
\text { crisis can be partly attributed to the large pass-through of } \\
\text { exchange rate shocks to CPI, the breakdown in its domestic } \\
\text { distribution networks, and the central bank's monetary policy } \\
\text { reaction to depreciation. }\end{array}$ \\
\hline $\begin{array}{l}\text { Barhoumi, } \\
\text { K. (2007) }\end{array}$ & $\begin{array}{l}\text { Quarterly. } 12 \\
\text { developing } \\
\text { countries. } \\
\text { 1980:1 - 2001:4. } \\
\text { To calculate PT } \\
\text { as the responses } \\
\text { of ER, CPI and }\end{array}$ & $\begin{array}{l}\text { Structural VECM and } \\
\text { the common trends } \\
\text { approach. All five } \\
\text { variables in logs. } \\
\text { Proxies of GDP: } \\
\text { industrial production, } \\
\text { petroleum production, }\end{array}$ & $\begin{array}{l}\text { Adopts a new formulation to show that PT to both CPI and } \\
\text { import prices are in general greater than one, indicating that } \\
\text { developing countries face larger shocks. ERPT is higher in } \\
\text { the higher inflation environments of developing countries, } \\
\text { showing that inflation is an important determinant of such } \\
\text { countries' PT. }\end{array}$ \\
\hline
\end{tabular}




\begin{tabular}{|c|c|c|c|}
\hline & $\begin{array}{l}\text { import prices to } \\
\text { the supply, the } \\
\text { relative demand, } \\
\text { the nominal and } \\
\text { the foreign } \\
\text { prices shocks. }\end{array}$ & $\begin{array}{l}\text { manufacturing } \\
\text { production. Nominal } \\
\text { and real effective } \\
\text { exchange rate. } \\
\text { Consumer price index, } \\
\text { import unit values. }\end{array}$ & $\begin{array}{l}\text { Demand shocks raise both domestic and import prices, and } \\
\text { depreciate nominal exchange rate. Supply shocks lower both } \\
\text { domestic and import prices and appreciate nominal exchange } \\
\text { rate. Nominal shocks increase all nominal variables. Foreign } \\
\text { shocks raise both domestic and import prices. CPI rises } \\
\text { higher than import prices. }\end{array}$ \\
\hline $\begin{array}{l}\text { Shambaugh } \\
\text { J. (2008) }\end{array}$ & $\begin{array}{l}\text { Quarterly. } 16 \\
\text { countries, } \\
\text { developed and } \\
\text { developing. } \\
\text { Data from 1973- } \\
\text { 1994. To } \\
\text { identify shocks } \\
\text { and explore the } \\
\text { way domestic } \\
\text { prices, import } \\
\text { prices and } \\
\text { exchange rates } \\
\text { react to these } \\
\text { shocks. }\end{array}$ & $\begin{array}{l}\text { Long-run restrictions } \\
\text { VAR. Variables in logs: } \\
\text { industrial production as } \\
\text { proxy of GDP, nominal } \\
\text { and real exchange rates } \\
\text { series are based on } \\
\text { relative CPI, import } \\
\text { prices (y, q, p, s and } \\
\text { pm) }\end{array}$ & $\begin{array}{l}\text { Supply shocks lower prices, appreciate nominal rates and } \\
\text { lower import prices. Demand shocks have a positive impact } \\
\text { on output in the short run, depreciate the real exchange rate, } \\
\text { raise domestic prices a small amount but raise import prices } \\
\text { permanently. Nominal shocks have a positive impact on } \\
\text { industrial production, depreciate the nominal exchange rate } \\
\text { and increase all the nominal variables. Foreign shocks } \\
\text { depreciate nominal exchange rates. However, supply and } \\
\text { nominal shocks are much larger in developing countries, } \\
\text { while the effect of a demand shock is somewhat weaker in } \\
\text { industrialized countries. }\end{array}$ \\
\hline $\begin{array}{l}\text { Barhoumi, } \\
\text { K. and } \\
\text { Jouini, J. } \\
\text { (2008) }\end{array}$ & $\begin{array}{l}\text { Quarterly. Eight } \\
\text { developing } \\
\text { countries. } \\
\text { 1980:2 - 2003:4. } \\
\text { To revisit the } \\
\text { Taylor (2000) } \\
\text { proposition. }\end{array}$ & $\begin{array}{l}\text { Structural change and } \\
\text { cointegration tests } \\
\text { suitable for the single } \\
\text { equation case. Five } \\
\text { variables in logs: } \\
\text { Percentage change of } \\
\text { CPI. Nominal and real } \\
\text { effective exchange rates. } \\
\text { Industrial price index } \\
\text { and import unit value. }\end{array}$ & $\begin{array}{l}\text { During the 1990s some developing countries experienced a } \\
\text { significant fall in inflation induced by a shift in their } \\
\text { monetary policy regimes that specifically targeted inflation. }\end{array}$ \\
\hline $\begin{array}{l}\text { Barhoumi, } \\
\text { K (2005) }\end{array}$ & $\begin{array}{l}\text { Annual. } 24 \\
\text { developing } \\
\text { countries. 1980- } \\
2003 \text {. } \\
\text { To define and } \\
\text { estimate ERPT. }\end{array}$ & $\begin{array}{l}\text { Nonstationary panel } \\
\text { techniques. Four } \\
\text { variables in logs: } \\
\text { nominal effective } \\
\text { exchange rate, } \\
\text { wholesale price index, } \\
\text { producer price index, } \\
\text { GDP, import unit value } \\
\text { in domestic currency. }\end{array}$ & $\begin{array}{l}\text { The long-run exchange rate pass-through is heterogeneous, } \\
\text { depending on local monetary policy and country size. The } \\
\text { long-run ERPT is determined by a combination of the } \\
\text { nominal effective exchange rate, the price of the competing } \\
\text { domestic products, the exporter's cost and domestic demand } \\
\text { conditions. }\end{array}$ \\
\hline $\begin{array}{l}\text { Rowland, } \\
\text { P. (2004) }\end{array}$ & $\begin{array}{l}\text { Monthly. } 20 \\
\text { years of data } \\
\text { from 1983- } \\
\text { 2002. To study } \\
\text { ERPT to import, }\end{array}$ & $\begin{array}{l}\text { UVAR using the } \\
\text { Johansen framework. } \\
\text { Variables in logs and } \\
\text { seasonally adjusted: } \\
\text { nominal bilateral }\end{array}$ & $\begin{array}{l}\text { Import prices respond rapidly to an exchange rate shock. } \\
\text { Producer and consumer prices respond much more } \\
\text { sluggishly. }\end{array}$ \\
\hline
\end{tabular}




\begin{tabular}{|c|c|c|c|}
\hline & $\begin{array}{l}\text { producer and } \\
\text { consumer prices } \\
\text { in Colombia. }\end{array}$ & $\begin{array}{l}\text { USD/COP rate of } \\
\text { exchange (because the } \\
\text { trade weighted nominal } \\
\text { effective exchange rate } \\
\text { residuals did not pass } \\
\text { the test of normality. } \\
\text { Besides, the US is by far } \\
\text { Colombia's largest } \\
\text { trading partner and a } \\
\text { large majority of } \\
\text { exports and imports are } \\
\text { priced in US dollars), } \\
\text { and all prices from the } \\
\text { distribution chain. }\end{array}$ & \\
\hline $\begin{array}{l}\text { Carranza, } \\
\text { Galdon } \\
\text { Sanchez } \\
\text { and Gomez } \\
\text { Biscarri } \\
(2004)\end{array}$ & $\begin{array}{l}\text { Monthly. } 15 \\
\text { countries with } \\
\text { different } \\
\text { degrees of } \\
\text { dollarization. } \\
\text { 1991-2003. }\end{array}$ & $\begin{array}{l}\text { OLS to time series. As a } \\
\text { measure of inflation 12- } \\
\text { month CPI inflation } \\
\text { rate, nominal exchange } \\
\text { rate vis-à-vis the dollar } \\
\text { and an indicator of } \\
\text { recessionary periods } \\
(\mathrm{Rc}) \text {. }\end{array}$ & $\begin{array}{l}\text { Pass-through is significantly higher in dollarized countries. } \\
\text { The asymmetry in the pass-through depends on the economic } \\
\text { cycle: the PT during recessions tends to be negative (the } \\
\text { more markedly so, the higher the degree of dollarization in } \\
\text { the economy), because the drop in the aggregate demand } \\
\text { prevents domestic prices rising. }\end{array}$ \\
\hline $\begin{array}{l}\text { Reinhart, } \\
\text { C., Rogoff, } \\
\text { K. and } \\
\text { Savastano, } \\
\text { M. (2003) }\end{array}$ & $\begin{array}{l}\text { Annual: two } \\
\text { samples: } 89 \\
\text { countries from } \\
\text { 1996-2001. }\end{array}$ & $\begin{array}{l}\text { Panel data. CPI, real } \\
\text { exchange rate, GDP and } \\
\text { proxies to control for } \\
\text { the openness of country } \\
\text { and other variables such } \\
\text { as seigniorage and the } \\
\text { level of dollarization of } \\
\text { each country. }\end{array}$ & $\begin{array}{l}\text { The exchange rate pass-through to prices was greatest in } \\
\text { economies where the degree of dollarization was very high, } \\
\text { suggesting a link between "fear of floating" and the degree of } \\
\text { dollarization: countries tend to be less tolerant to large } \\
\text { exchange rate changes out of concern for the adverse effects } \\
\text { such changes may have on sectoral balance sheets and, } \\
\text { ultimately, on aggregate output. }\end{array}$ \\
\hline $\begin{array}{l}\text { Bhundia, A. } \\
(2002)\end{array}$ & $\begin{array}{l}\text { Quarterly from } \\
1980-2001 . \\
\text { To analyze the } \\
\text { ERPT, to } \\
\text { distinguish } \\
\text { between real } \\
\text { and nominal } \\
\text { shocks and to } \\
\text { investigate their } \\
\text { impact on the } \\
\text { exchange rate } \\
\text { and prices. } \\
\text { South Africa }\end{array}$ & $\begin{array}{l}\text { VAR with long run } \\
\text { restrictions. Six } \\
\text { variables based on } \\
\text { McCarthy (1999): oil } \\
\text { prices, output gap, } \\
\text { nominal effective } \\
\text { exchange rate (the } \\
\text { results using the } \\
\text { bilateral exchange } \\
\text { rand/US dollar are } \\
\text { similar), import prices, } \\
\text { producer prices and } \\
\text { CPI. A dummy variable } \\
\text { to control for the change } \\
\text { in } 1994 \text { with the post } \\
\text { apartheid government }\end{array}$ & $\begin{array}{l}\text { Shocks to producer prices have a considerable impact on } \\
\text { CPI. When real shocks are responsible for nominal exchange } \\
\text { rate depreciation the response of inflation is much smaller. }\end{array}$ \\
\hline $\begin{array}{l}\text { Gonzalez } \\
\text { Anaya, } \\
\text { J.A.. (2000) }\end{array}$ & $\begin{array}{l}\text { Monthly. Data } \\
\text { from 1980- } \\
2000.16\end{array}$ & $\begin{array}{l}\text { Error Correction Model } \\
\text { and Panel Data. } \\
\text { Nominal dollar }\end{array}$ & $\begin{array}{l}\text { There is no significant cross-country or within-country } \\
\text { correlation between dollarization and pass-through. }\end{array}$ \\
\hline
\end{tabular}




\begin{tabular}{|c|c|c|c|}
\hline & $\begin{array}{l}\text { dollarized } \\
\text { countries of } \\
\text { Latin America }\end{array}$ & $\begin{array}{l}\text { exchange rate. CPI, US } \\
\text { PPI, G7 PPI as } \\
\text { international prices. M4. }\end{array}$ & \\
\hline $\begin{array}{l}\text { Goldfajn, I } \\
\text { and } \\
\text { Werlang, S. } \\
(2000)\end{array}$ & $\begin{array}{l}71 \text { countries } \\
\text { from } 1980-1998\end{array}$ & $\begin{array}{l}\text { Panel Data. GDP gap, } \\
\text { accumulated inflation } \\
\text { calculated as the } \\
\text { difference between CPI } \\
\text { index at } \mathrm{t}+12 \text { and } \mathrm{t} \text {, } \\
\text { proxy for trade } \\
\text { openness, depreciation } \\
\text { as changes in effective } \\
\text { nominal exchange rate, } \\
\text { and a proxy to capture } \\
\text { the misalignment of the } \\
\text { real exchange rate. }\end{array}$ & $\begin{array}{l}\text { The PT coefficient increase as the time horizon of the } \\
\text { regression is expanded. American and Asian regions have a } \\
\text { higher ERPT to prices than that of the other regions. The } \\
\text { economically significant determinants are the degree of ER } \\
\text { overvaluation and initial inflation. }\end{array}$ \\
\hline
\end{tabular}




\section{Appendix B Figures}

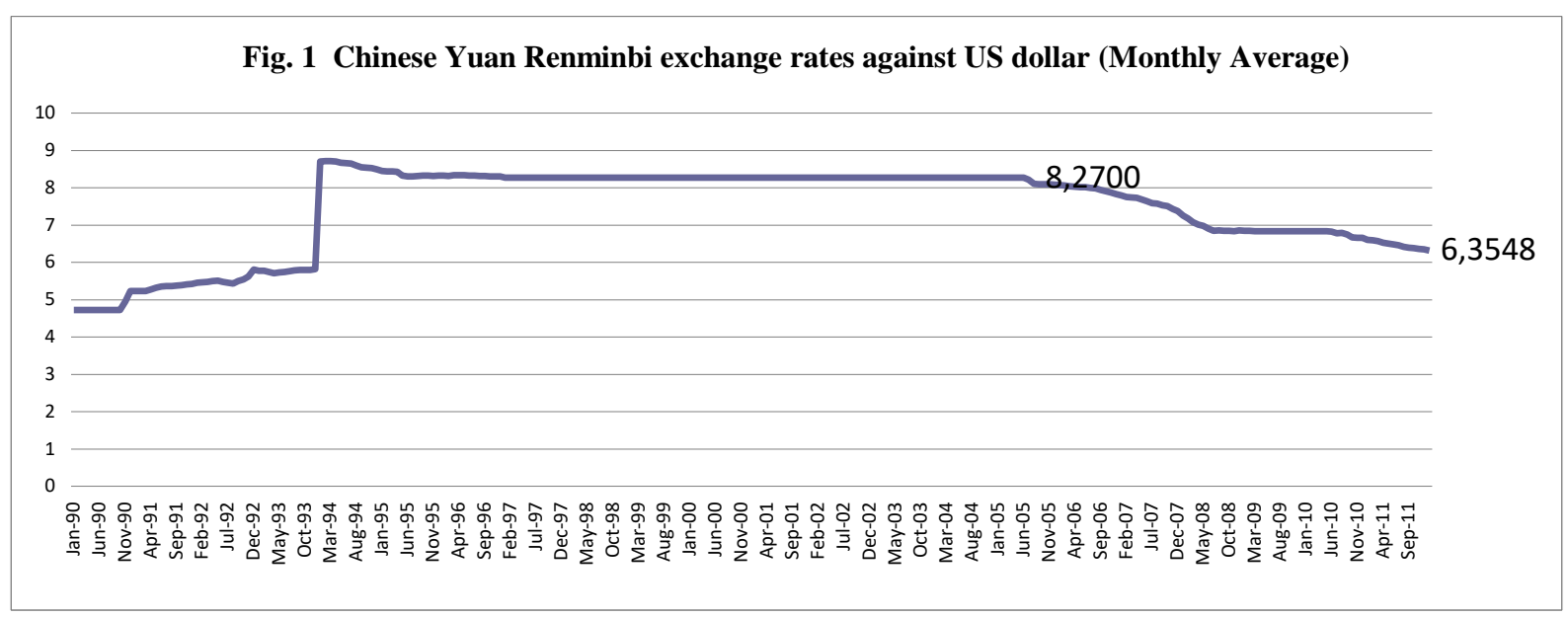

Source: http://fxtop.com.

Notes: Fig. 1 shows the appreciation of CNY/USD since China reformed its fixed exchange rate regime to a managed floating exchange rate system in July 2005.

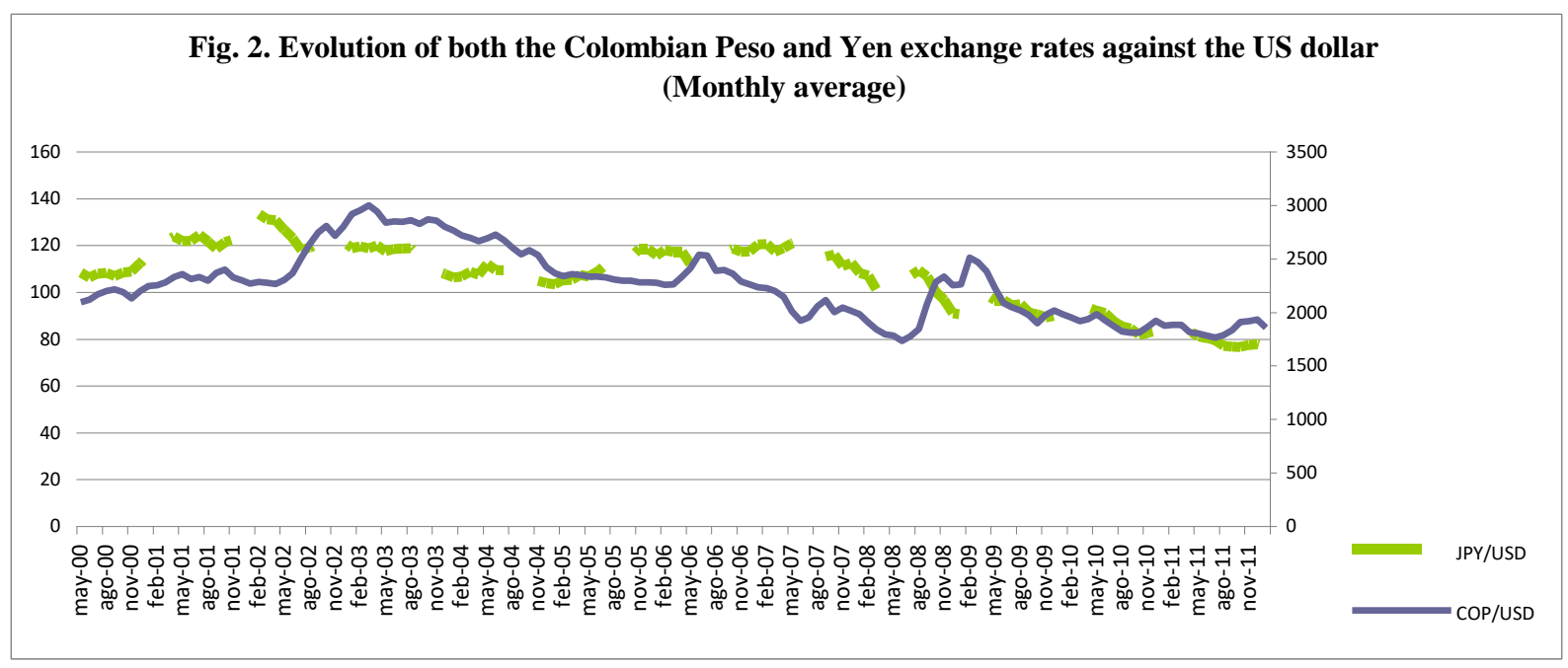

Source: http://fxtop.com

Notes: Fig. 2 shows the appreciation of two currencies belonging to two of Ecuador's main trading partner Colombia and Japan. 
Fig. 3 Ecuador imports CIF by region (\$US Millions)

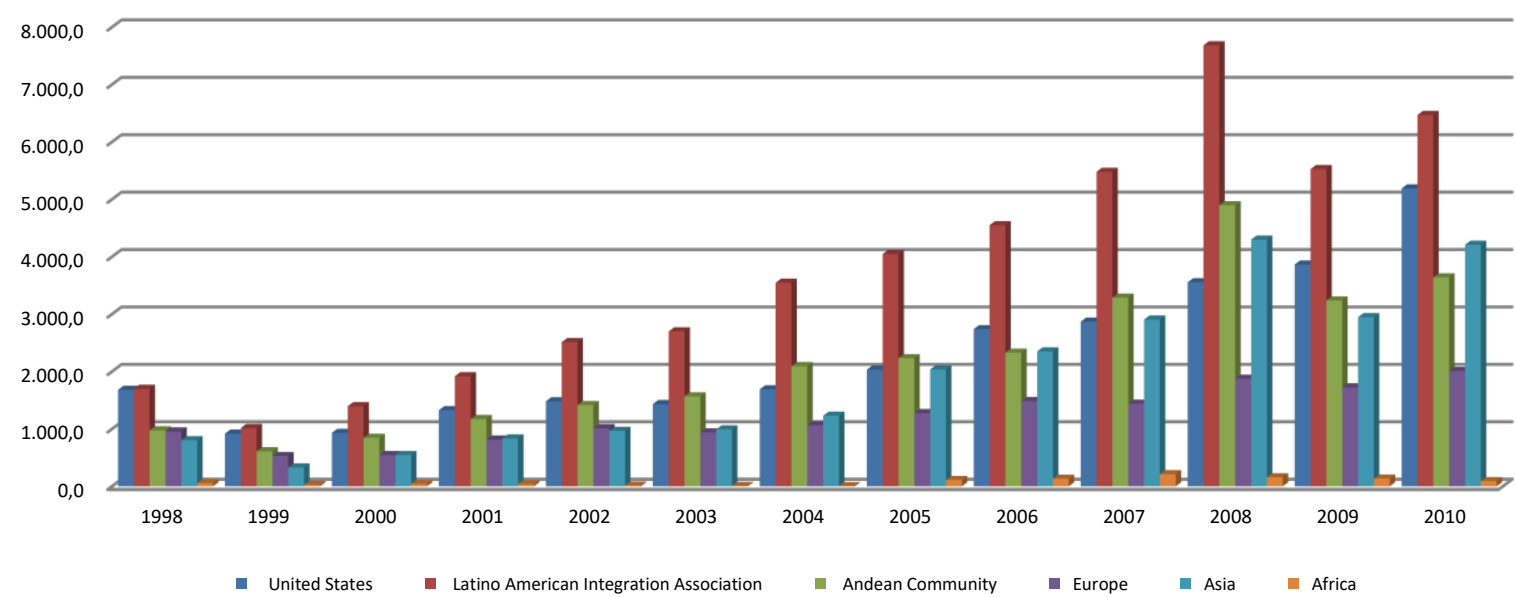

Source: Based on statistics provided by the Central Bank of Ecuador.

Notes: Fig. 3 shows the evolution in Ecuador's main suppliers: the most important are the United States, the Latin American Integration Association (Argentina, Brazil, Chile and Mexico) and the Andean Community (Bolivia, Colombia, Peru and Venezuela). The picture also shows the growth recorded by Asia (comprising Japan, Taiwan, China and South Korea), which since 2004 has replaced Europe as the third largest source of imports. 


\section{Appendix C. Econometric analysis}

\section{Graphics of the variables in logarithms}

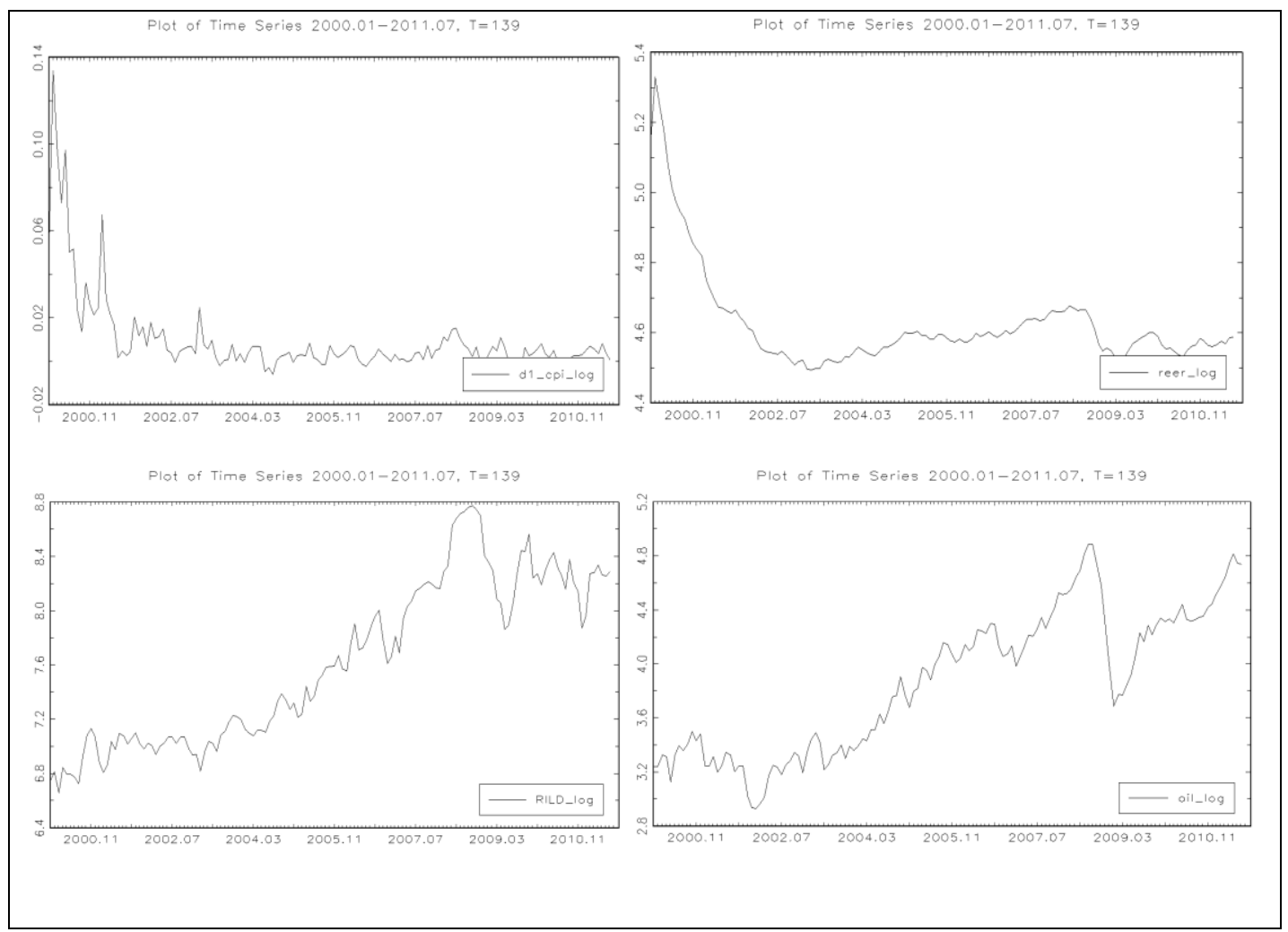

\section{Unit root and cointegration tests.}

Table 1. Unit root with structural break test (Saikkonen and Lütkepohl, 2002 and Lanne et al., 2002).

\begin{tabular}{|c|c|c|c|c|c|c|c|}
\hline \multirow{2}{*}{ Variable } & \multirow{2}{*}{ Deterministic terms* } & \multirow{2}{*}{ Lags } & \multirow{2}{*}{ Break date } & \multirow{2}{*}{$\begin{array}{l}\text { Value of } \\
\text { test } \\
\text { statistic }\end{array}$} & \multicolumn{3}{|c|}{ Critical Values (Lanne, 2002) } \\
\hline & & & & & $1 \%$ & $5 \%$ & $10 \%$ \\
\hline d1_cpi_log & $\mathrm{C}+$ Time trend + ID + SD & 1 & 2001M2 & -2.2576 & -3.55 & -3.03 & -2.76 \\
\hline$d 1 \_c p i \_l o g \_d 1$ & ID & 0 & $2001 \mathrm{M} 2$ & -14.6855 & -3.48 & -2.88 & -2.58 \\
\hline reer_log & C + Time trend + Shift D & 1 & $2001 \mathrm{M} 2$ & 0.1508 & -3.55 & -3.03 & -2.76 \\
\hline reer_log_dl & ID & 0 & $2001 \mathrm{M} 2$ & -5.8671 & -3.48 & -2.88 & -2.58 \\
\hline oil_log & C + Time trend + Shift D & 1 & 2008M12 & -2.9592 & -3.55 & -3.03 & -2.76 \\
\hline oil_log_dl & ID & 0 & 2009M1 & -10.0459 & -3.48 & -2.88 & -2.58 \\
\hline
\end{tabular}


Table 2. ADF Test (Fuller, 1976, Dickey and Fuller, 1979)

\begin{tabular}{|c|c|c|c|c|c|c|}
\hline \multirow[t]{2}{*}{ Variable } & \multirow[t]{2}{*}{ Deterministic terms* } & \multirow[t]{2}{*}{ Lags } & \multirow[t]{2}{*}{$\begin{array}{l}\text { Value of test } \\
\text { statistic }\end{array}$} & \multicolumn{3}{|c|}{$\begin{array}{l}\text { Critical Values (Davidson and } \\
\text { MacKinnon, 1993) }\end{array}$} \\
\hline & & & & $1 \%$ & $5 \%$ & $10 \%$ \\
\hline$R I D L \_l o g$ & $\mathrm{C}+$ Time trend $+\mathrm{SD}$ & 0 & -2.1764 & -3.96 & -3.41 & -3.13 \\
\hline$R I D L \_l o g \_d l$ & $\mathrm{C}+\mathrm{SD}$ & 0 & -10.8122 & -3.43 & -2.86 & -2.57 \\
\hline${ }^{*} \mathrm{C}:$ & mmies & & & & & \\
\hline
\end{tabular}

Table 3. Cointegration test between $d 1_{-} c p i$, reer, RIDL and oil variables (Saikkonen \& Lütkepohl, 2000).

\begin{tabular}{|c|c|c|c|c|c|}
\hline \multirow{2}{*}{ r0 } & LR & p value & \multicolumn{3}{|c|}{ Critical Values (Trenkler, 2004) } \\
& & & $90 \%$ & $95 \%$ & $59 \%$ \\
\hline 0 & 85.68 & 0.0000 & 42.05 & 45.32 & 33.50 \\
\hline 1 & 25.27 & 0.1234 & 26.07 & 15.76 & 9.73 \\
\hline 2 & 5.25 & 0.8483 & 13.88 & 6.79 & 9.73 \\
\hline 3 & 0.15 & 0.9877 & 5.47 & & \\
\hline
\end{tabular}

\section{Table 4. VECM Estimation Results}

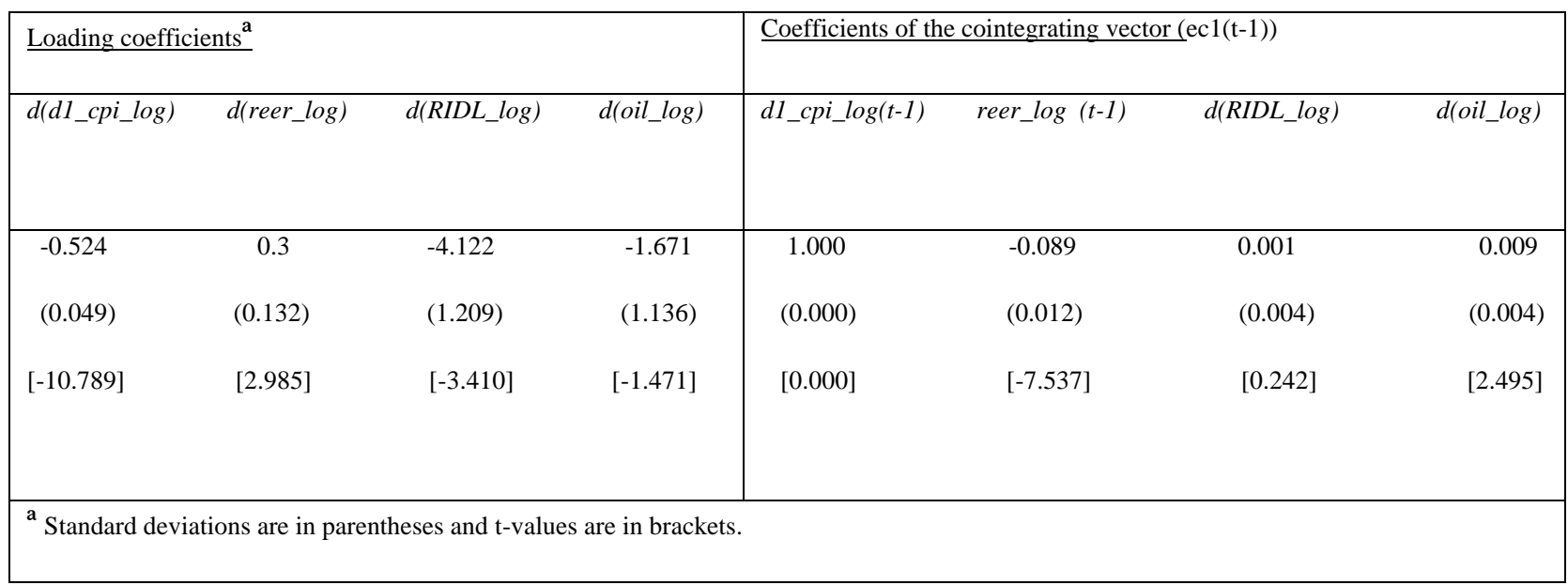


Table 5. Structural VEC Estimation Results. Coefficients of the $B$ matrix ${ }^{a}$.

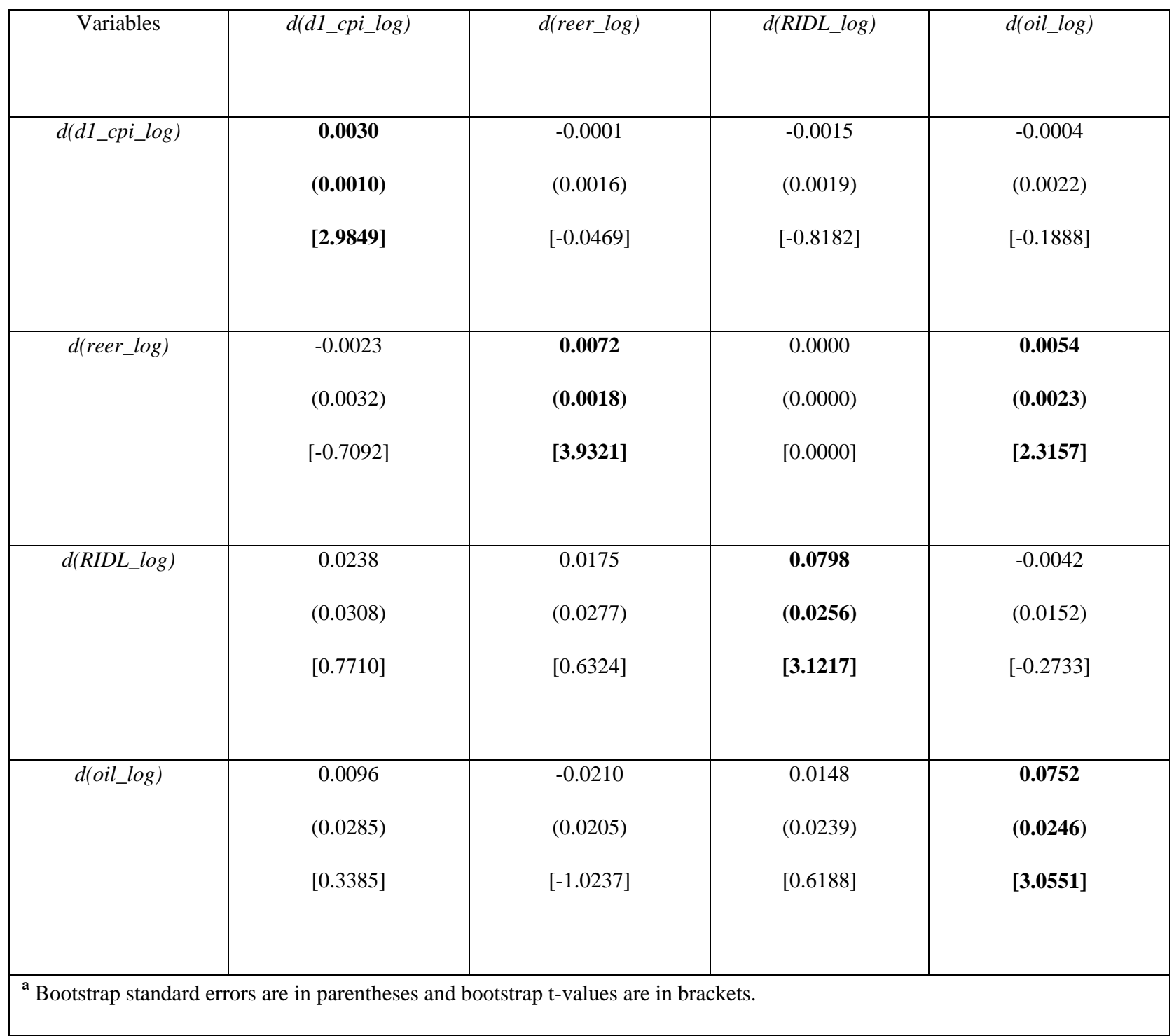


Table 5 (continuation). Coefficients of the long run impact matrix $\Xi B$.

\begin{tabular}{|c|c|c|c|c|}
\hline Variables & $d\left(d 1 \_c p i \_l o g\right)$ & $d($ reer_log) & $d\left(R I D L \_l o g\right)$ & $d($ oil_log) \\
\hline$d\left(d 1 \_c p i \_l o g\right)$ & $\begin{array}{c}0.0000 \\
(0.0000) \\
{[0.0000]}\end{array}$ & $\begin{array}{c}0.0024 \\
(0.0011) \\
{[2.1669]}\end{array}$ & $\begin{array}{l}-0.0009 \\
(0.0015) \\
{[-0.5539]}\end{array}$ & $\begin{array}{c}0.0009 \\
(0.0041) \\
{[0.2154]}\end{array}$ \\
\hline$d($ reer_log $)$ & $\begin{array}{c}0.0000 \\
(0.0000) \\
{[0.0000]}\end{array}$ & $\begin{array}{c}0.0274 \\
(0.0126) \\
{[2.1803]}\end{array}$ & $\begin{array}{l}-0.0090 \\
(0.0171) \\
{[-0.5252]}\end{array}$ & $\begin{array}{c}0.0197 \\
(0.0561) \\
{[0.3507]}\end{array}$ \\
\hline$d\left(R I D L \_l o g\right)$ & $\begin{array}{l}0.0000 \\
(0.0000) \\
{[0.0000]}\end{array}$ & $\begin{array}{c}0.0038 \\
(0.0224) \\
{[0.1718]}\end{array}$ & \begin{tabular}{|l}
0.0562 \\
$(0.0277)$ \\
{$[2.0276]$}
\end{tabular} & $\begin{array}{c}0.0495 \\
(0.1093) \\
{[0.4526]}\end{array}$ \\
\hline$d($ oil_log $)$ & $\begin{array}{c}0.0000 \\
(0.0000) \\
{[0.0000]}\end{array}$ & $\begin{array}{c}0.0000 \\
(0.0000) \\
{[0.0000]}\end{array}$ & $\begin{array}{c}0.0000 \\
(0.0239) \\
{[0.0000]}\end{array}$ & $\begin{array}{c}0.0876 \\
(0.1529) \\
{[0.5728]}\end{array}$ \\
\hline \multicolumn{5}{|c|}{$\begin{array}{l}\text { Notes: This is a B-model with long-run restrictions. With long-run restrictions providing five independent } \\
\text { restrictions and one contemporaneous restriction providing one additional restriction, the Structural VAR is } \\
\text { just identified. ML Estimation, Scoring Algorithm (see Amisano \& Giannini, 1992). Convergence after } 11 \\
\text { iterations. Log Likelihood: } 1791.3097\end{array}$} \\
\hline
\end{tabular}


Fig. 6. Impulse responses

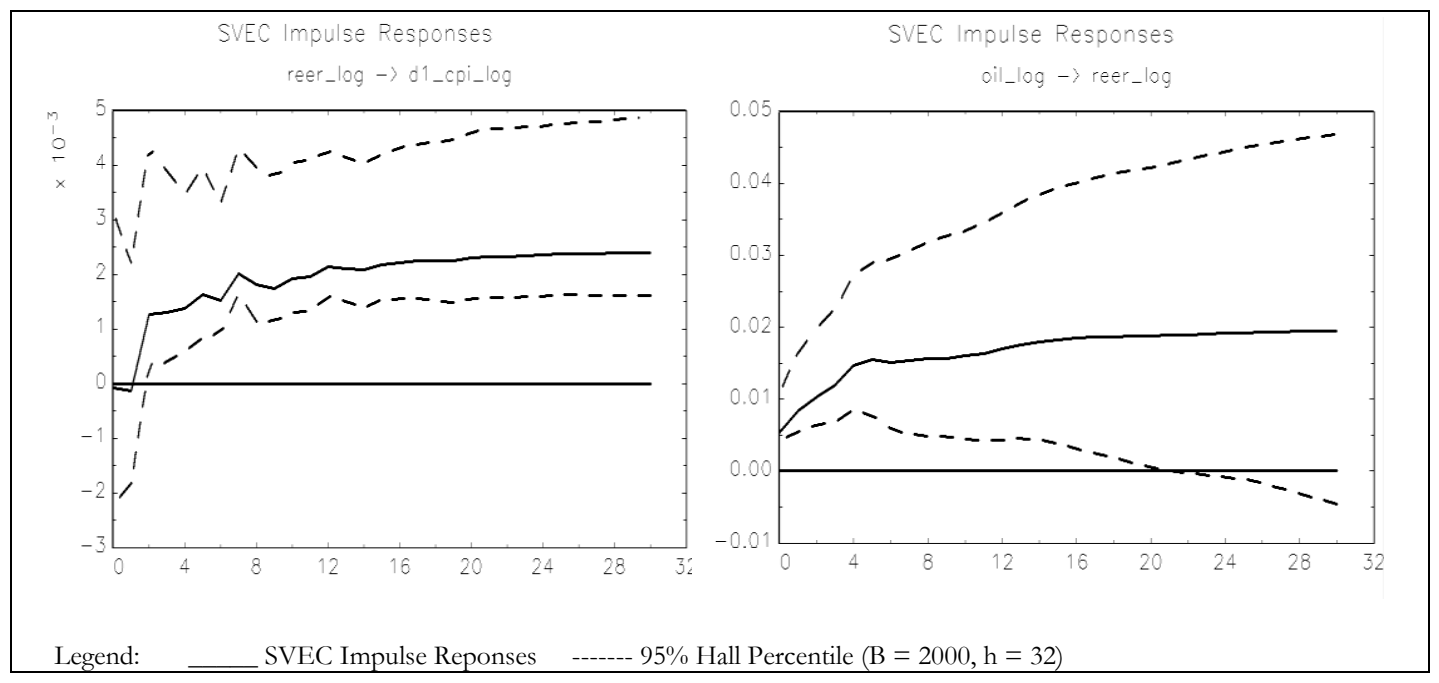

Table 6. SVEC Forecast error variance decomposition of "d1_cpi_log"

\begin{tabular}{|lllll|}
\hline Forecast Horizon & $d 1 \_c p i-l o g$ & reer_log & RIDL_log & oil_log \\
\hline 1 & 0.78 & 0.00 & 0.20 & 0.01 \\
\hline 2 & 0.76 & 0.00 & 0.23 & 0.01 \\
\hline 3 & 0.67 & 0.08 & 0.24 & 0.01 \\
\hline 4 & 0.61 & 0.14 & 0.24 & 0.01 \\
\hline 5 & 0.55 & 0.20 & 0.22 & 0.03 \\
\hline 6 & 0.50 & 0.27 & 0.20 & 0.03 \\
\hline 7 & 0.46 & 0.31 & 0.18 & 0.05 \\
\hline 8 & 0.42 & 0.37 & 0.15 & 0.05 \\
\hline 9 & 0.39 & 0.41 & 0.14 & 0.06 \\
\hline 10 & 0.36 & 0.44 & 0.14 & 0.06 \\
\hline 11 & 0.33 & 0.47 & 0.13 & 0.06 \\
\hline 12 & 0.30 & 0.50 & 0.14 & 0.06 \\
\hline 13 & 0.27 & 0.53 & 0.13 & 0.06 \\
\hline 14 & 0.25 & 0.55 & 0.13 & 0.06 \\
\hline 15 & 0.23 & 0.57 & 0.13 & 0.06 \\
\hline 16 & 0.22 & 0.59 & 0.13 & 0.06 \\
\hline 17 & 0.20 & 0.61 & 0.13 & 0.07 \\
\hline 18 & 0.19 & 0.62 & 0.12 & 0.07 \\
\hline 19 & 0.18 & 0.63 & 0.12 & 0.07 \\
\hline 20 & 0.16 & 0.64 & 0.12 & 0.08 \\
\hline & & & & \\
\hline
\end{tabular}

